\title{
全水分およひ湿分
}

鉄道挂術研究所 金松 正。世

\section{榴 要}

（1）全水分測定に関する若干の笑験起行い，全水分 測定法の改訂原案老作成乙沈。(2) 湿分については 現行法のほか江全水分と工業分析水分から計算する。

\section{I 全水分測定法改豤の必要性}

全水分は熱精算学行万之きの必要不可欠の基礎デー タであり，また最近は国際取引沉じしば使用されて いるため，全水分測定の精度向上が望るれている。わ が国では全水分測定や゙縮分の誤差について検討された 資料に乏しいので今回若干の試験を行い参考供する こととする。

JIS M 8802 では全水分について次の 2 通りの定義 を行っている。

第 1 定義，全水分 $\%=$ =湿分 $\%+$ 分析水分 $\% \times$

$$
\frac{100-\text { 湿分 } \%}{100}
$$

\section{第 2 定義 全水分 $\%=\frac{\text { 熱乾燥減量 }}{\text { 全水分試料重量 }} \times 100$}

第 1 定義に上る全水分注湿分測定に長時間を要し， また測定に確実性が泛しいため，第2定義による測定 が多くの場合実施されている。外国1では

2 段法の全水分 $\%=$ 気乾隇量 $\%+$ 熱乾燥减量 $\%$

$$
\times \frac{100-\text { 気乾減量 } \%}{100}
$$

が用いられているし，第 2 定義は 1 段法の全水分\%と 乙て用いられている。装た熱乾燥隇量\%を測定する代
りにトルエンなたはキシレンとの共沸蒸留法る実施さ れている。蓺乾燥減量を測定する際に石炭の酸化を防 ぐため，咥素気流中で行うことを規定している所もあ る。本報告では熱乾燥中比較的酸化され難い志免宸(水 分約 $3 \%$ ）を試料として検討した。

\section{II 第 1 回実験 気乾状態の $3 \mathrm{~mm}$ 詿料について縮分誤差}

測定䛊差を推定する目的で第 1 回実験を行つた。

(1) 試験訫画と測定法 試験訂画は第1図に示 す。 $3 \mathrm{~mm}$ 圾料の粒度は $2,830 \mu$ 以上 $1.9 \% ， 2,830$ $2,000 \mu \quad 9.7 \%, 2,000 \sim 1,000 \mu \quad 47.9 \%, 1,000 \sim 250 \mu$ $30.5 \%, 250 \mu$ 以下 $10 \% 。 500 \mathrm{~g}$ 試料を10分割して夫々 から $5 \mathrm{~g}$ を 2 個とつて平形とヨウ量ビン（径 $45 \mathrm{~mm}$, 高サ $30 \mathrm{~mm}$ ) で $105 \sim 110^{\circ} \mathrm{C}$ の空気中で熱乾燥し，1 時間每にとり出して重量を測定。

（2）試験結果 第 1 表に示す試験結果を得た。残 りの試料を $0.25 \mathrm{~mm}$ 以下に粉粋して $1 \mathrm{~g}$ 試料で工業分 析潐じて熱榦燥減量\%を測定したが，平均 3.18\%， 最高 3.73 , 最低 2.71 となり見排上縮分誤差が非常に大 きくなつた。これは微粉砕のとき大気の湿度涼響さ れたり, 粉研熱による作用のため生じたるので市ら 5。

(3) 結 論

a. 全水分試料は最大粒径 $0.25 \mathrm{~mm}$ 亿微粉碟して はいけない。

\section{第 1 図 $3 \mathrm{~mm}$ 試料縮分分析誤差推定宒験計画}

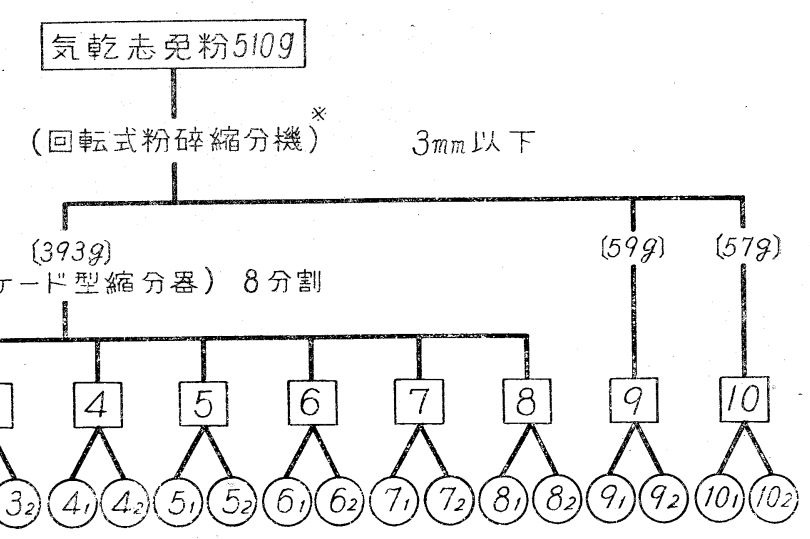


第 1 表 $3 \mathrm{~mm}$ 試㪶試験結果

\begin{tabular}{|c|c|c|c|c|c|c|c|c|c|}
\hline 試料 & & 燥 & 間 & & 試料 & & 乾 & 時 & \\
\hline 番号 & 1 時間 & 2 時間 & 3 時間 & 4 時間 & 番号 & 1 時間 & 2 時間 & 3 時間 & 4 時間 \\
\hline $\begin{array}{l}1_{1} \\
1_{2}\end{array}$ & $\begin{array}{l}2.73 \\
2.84\end{array}(2.79)$ & & & & $\begin{array}{l}7_{1} \\
7_{2}\end{array}$ & $\begin{array}{l}2.84 \\
2.96\end{array}(2.90)$ & $\begin{array}{l}3.02 \\
3.08\end{array}(3.05)$ & $\begin{array}{l}3.07 \\
3.11\end{array}(3.09)$ & $\begin{array}{l}3.10 \\
3.11\end{array}$ \\
\hline $\begin{array}{l}2_{1} \\
2_{2}\end{array}$ & $2.77(2.80)$ & & & & $\begin{array}{l}8_{1} \\
8_{2}\end{array}$ & $\begin{array}{l}2.85 \\
3.00\end{array}$ & $\begin{array}{l}3.00 \\
3.11\end{array}(3.06)$ & $\begin{array}{l}3.07 \\
3.13\end{array}(3.10)$ & $\begin{array}{l}3.08 \\
3.13\end{array}$ \\
\hline $\begin{array}{l}3{ }_{1} \\
3_{2}\end{array}$ & $2.73(2.80)$ & $\begin{array}{l}2.92 \\
3.01\end{array}$ & & & $\begin{array}{l}9_{1} \\
9_{2}\end{array}$ & $\begin{array}{l}2.86 \\
2.80\end{array}(2.83)$ & $\begin{array}{l}3.00 \\
2.97\end{array}$ & $\begin{array}{l}3.05 \\
3.03\end{array}(3.04)$ & $\begin{array}{l}3.07 \\
3.05\end{array}$ \\
\hline $\begin{array}{l}4_{1} \\
4_{2}\end{array}$ & $\begin{array}{l}2.91 \\
2.91\end{array}$ & $\begin{array}{l}3.01 \\
3.01\end{array}$ & & & $\begin{array}{l}10_{1} \\
10_{2}\end{array}$ & $\begin{array}{l}2.82 \\
2.93\end{array}$ & $\begin{array}{l}2.99 \\
3.07\end{array}(3.03)$ & $\begin{array}{l}3.03 \\
3.11\end{array}(3.07)$ & $\begin{array}{l}3.06 \\
3.12\end{array}$ \\
\hline $\begin{array}{l}5_{1} \\
5_{2}\end{array}$ & $\begin{array}{l}2.75 \\
2.89\end{array}(2.82)$ & $\begin{array}{l}2.97 \\
3.02\end{array}(3.00)$ & $\begin{array}{l}3.03 \\
3.03\end{array}(3.03)$ & & 平均 & 2.855 & 3.02 & 3.0725 & 3.09 \\
\hline $\begin{array}{l}6_{1} \\
6_{2}\end{array}$ & $\begin{array}{l}2.88 \\
2.94\end{array}(2.91)$ & $\begin{array}{l}3.07 \\
3.07\end{array}(3.07)$ & $\begin{array}{l}3.12 \\
3.09\end{array}(3.11)$ & & $\begin{array}{l}\sigma_{M} \\
\sigma_{R}\end{array}$ & $\begin{array}{l}0.074 \\
0\end{array}$ & $\begin{array}{l}0.045 \\
0\end{array}$ & $\begin{array}{l}0.033 \\
0.02\end{array}$ & $\begin{array}{l}0.029 \\
0\end{array}$ \\
\hline
\end{tabular}

第 2 図第 2 実験計画

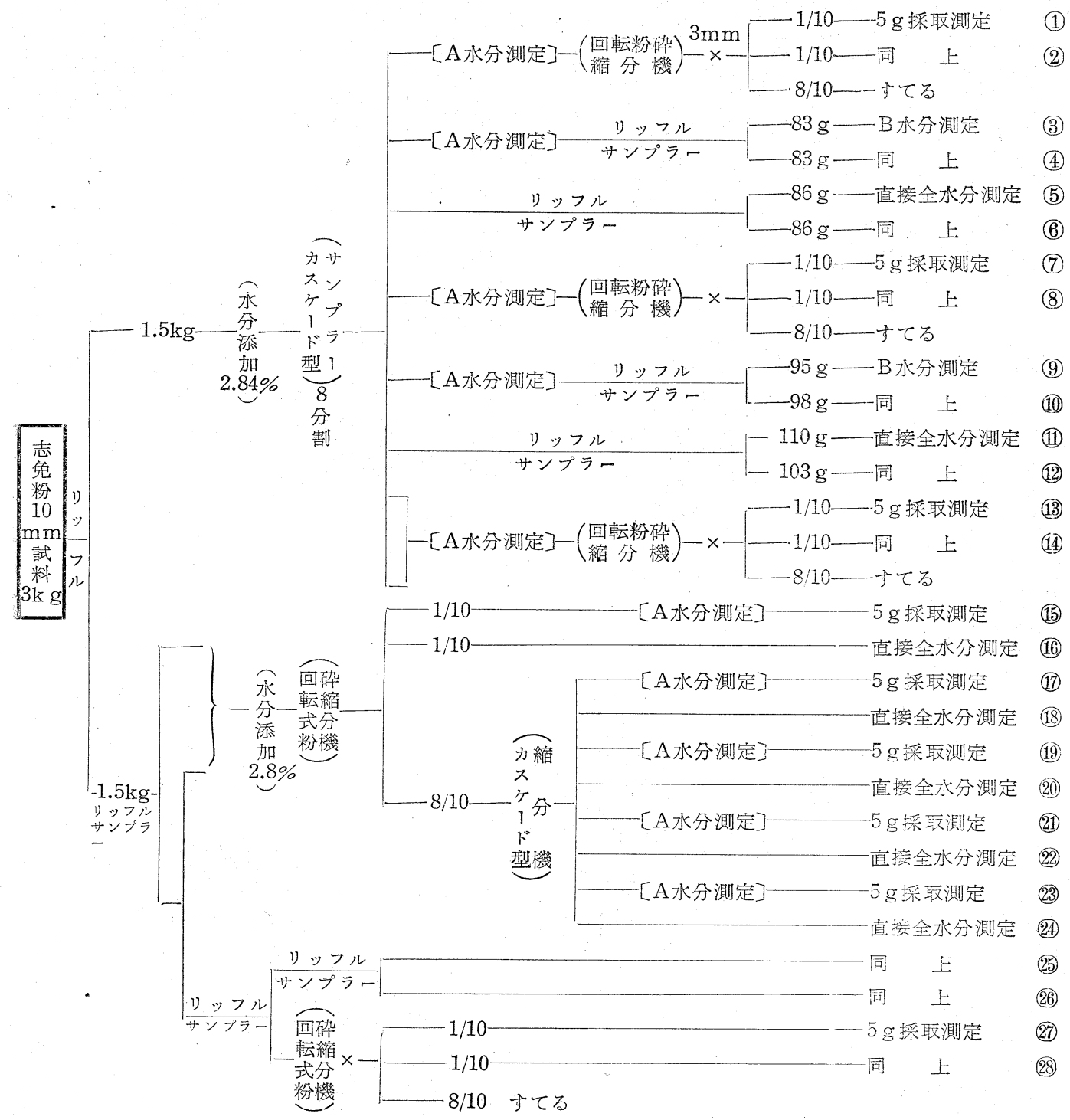




\section{第 2 表 第 2 実験計画による試験結果}

（熱乾燥 4 時間の全水分 $\%$ )

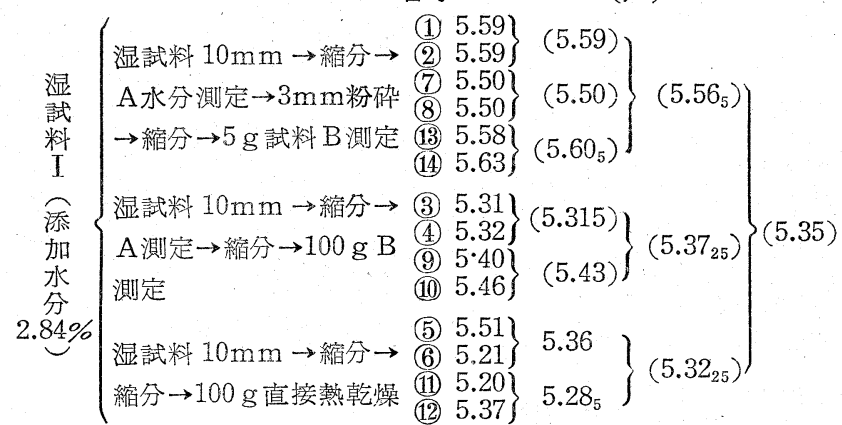

測定 順序試料全水分

$\mathrm{A}$ : 第 1 段乾燥減量\%

B : 第 2 段熱乾燥減量 $\%$

(3) 結 論

a. 濡孔分約 $2.8 \%$ の $10 \mathrm{~mm}$ 試料 $1.5 \mathrm{~kg}$ の 全水分推定の 精度は湿試料 $(10 \mathrm{~mm})$ を $200 \mathrm{~g}$ 程度に縮分してA水 分測定後 $3 \mathrm{~mm}$ に粉酔しょく混合して $5 \mathrm{~g}$ を採取し 105〜 $110^{\circ} \mathrm{C}$ で乾燥する 2 段法が最も良かつた。 $10 \mathrm{~mm}$ 湿試料 を1 段で熱乾燥する方法は最も精度が 悪い。悪いといつても $\sigma_{R M}=0.147 て ゙$ あるから実用上は差支えない程度であ る。

b，湿試料を予備乾燥せずに縮分す ると僅かではあるが縮分装置に濡分が 附着して全水分を過小評価する。今回 の実験ではその偏りは $0.22 \%$ であつ た。この程度の偏りは実用上あまり閒 題とするに足らないだろらが，正確を 期する上からは湿試料はA水分測定後 に粉砕縮分するのがよいといらことに なる。

\section{IV 協 同 実 験}

現在これらの点を再検討するための協 同帮験を行いこれを解析中である。した がつてその結果によつては，さらに JIS 原案も改訂されるか子知れない。

b. 最大粒径 $3 \mathrm{~mm}$ ではよい縮分法を採用すると 縮分訹差は殆どない。

c. 最大粒径 $3 \mathrm{~mm}$ の $5 \mathrm{~g}$ 試料では 2 3 時間の 105〜 $110^{\circ} \mathrm{C}$ 空気乾燥でほぼ終点に達し，そのときの 测定誤差は $\sigma_{M}=0.03 \sim 0.05$ で工業分析水分の測定誤 差の程度かそれ头下である。

d. 最大粒径 $3 \mathrm{~mm}$ の $5 \mathrm{~g}$ 試料だと測定装置は工業

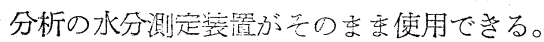

\section{III 第 2 回実験 全水分測定試料の粒度を最}

大 $10 \mathrm{~mm}$ とするか $3 \mathrm{~mm}$ とするかの判定

2 段乾燥法にするか 1 段乾燥法にするかの判定を行 5 ために第 2 回の矢験を行つた。

（1）試験計画と測定法 試験許画は第 2 困に示す。 $100 \mathrm{~g}$ 試料の乾燥皿は面積 $100 \mathrm{~cm}^{2}$ 高サ $2 \mathrm{~cm}$ の亜鉛鍍 鉄板製で，ヒヨウ量は熱いうちに行つた。

（2）試駘結果 第2 表に示すと和りである。2段 乾燥法の全水分\%は次式によつて訢算された。

$$
\text { 今水分\% }=\mathrm{A}+\mathrm{B} \times \frac{100-\mathrm{A}}{100}
$$

\section{JIS M 8802 の改訂すべき点}

（1）全水分の定義は全水分 $\%=\mathrm{A}+\mathrm{B} \times \frac{100-\mathrm{A}}{100}$ K 改める。

（2）湿試料は 2 段乾燥法を原則とし，A 水分は $10 \mathrm{~mm}$ 以上の段階で行う。実用上支障のないときは現 行法の $10 \mathrm{~mm} 100 \mathrm{~g}$ の 1 段乾燥法を存続させる。

(3) 湿試料でも $10 \mathrm{~mm}$ 以下に粉砕縮分が可能なと きは $1 \mathrm{~kg}$ まで縮分する湿分試料採取法を全水分試料採 取法として存続させる。

（4）B水分測定用試料の粒径は $10 \mathrm{~mm}, 3 \mathrm{~mm}$ の 何れでもよいが， $0.25 \mathrm{~mm}$ 以下にしてはならない。

（5）熱乾燥温度は石炭類については現行法を廃 し，国際的見地加ら $105 \sim 110^{\circ} \mathrm{C}$ にする。

（6）蓺乾燥終点は 1 時間について $0.1 \%$ 以下とす る。

（7）㙓乾燥雲困気は日本の実状として当分の間它: 気とする。 
（8）水分の多い褐炭，亚炭については酸化を少く するために全水分試料の粒度は大きくするのがよいこ とになろう。この点に関しては今後の研究にまたたねば ならない。

\section{V 改訂 原 案}

(1) 漏孔ている石崖で $10 \mathrm{~mm}$ 以下に粉砕出来ない 場合は大口試料全部を $35^{\circ} \mathrm{C}$ 以下で自然乾燥または通 風乾燥して $A$ 水分を求め, 次に $10 \mathrm{~mm}$ 以下粉础し, 適当な縮分方法で $200 \mathrm{~g}$ まで縮分し， $100 \mathrm{~g}$ ずつに分け て $107 \pm 2{ }^{\circ} \mathrm{C}$ で乾燥し，減量割合が 1 時間䏓さ $0.1 \%$ になつたら乾燥を終了し，B水分\%を求め，全水分\% を計算する。酸化の括それが少く急ぐときは $10 \mathrm{~mm}$ $200 \mathrm{~g}$ 試料を更に $3 \mathrm{~mm}$ 粉础して $5 \mathrm{~g}$ 試料について 107 $\pm 2^{\circ} \mathrm{C}$ の熱乾燥を行う。

（2） $10 \mathrm{~mm}$ 以下汾砕出来方場合は大口試料を速 かに粉础して $1 \mathrm{~kg}$ 以上に縮分し，A水分を求め,さら 飞 $200 \mathrm{~g}$ 飞縮分して前記 (1) と同じ方法でB水分を 求め全水分を計算する。

\section{VII 湿分について}

現行 JIS M 8802 で規定する湿分測定は恒湿状態に なつたかどうかの判定がむずかしく，炭種によつては 1 カ月以上の長時日を要する欠点がある。この欠点を 除くために現行の直接測定法のほかに次の計算による 定義を加觉ることとした。

湿分 $\%=$ 全水分 $\%$-(恒湿水分 $\%) \times \frac{100 \text { - 全水分 } \%}{100 \text { - 恒湿水分 } \%}$

全水分％: 前項 1 で測定した全水分\%

恒湿水分\%: 工業分析で恒湿試料について求め られた水分\%

銘柄が既知である場合, 恒湿水分はその銘柄につい て医济一定常数と見なされるものであるから每回測定 する必要のない場合が多く，全承分だけの測定をすれ ばよく，かつ全水分測定の方が湿分測定より短時間で すむことが多いので結局上式によつて計算により湿分 を求める方が迅速行われるからである。

この式は新しく定義されたようにみえるが，現行の JIS M 8802 の全水分の定義式を書替光たものに外な らない。濡秃た石炭中の純炭分を $a g$, 湿分を $w_{1} g$, 恒 湿水分を $w_{2} g$ とすれば

$$
\begin{aligned}
\text { 湿分\% } & M_{F^{r}}=\frac{w_{1}}{a+w_{1}+w_{2}} \times 100 \\
\text { 全水分\% } & M_{T}=\frac{w_{1}+w_{2}}{a+w_{1}+w_{2}} \times 100 \\
\text { 恒湿水分\% } & M_{A}=\frac{w_{2}}{a+w_{2}} \times 100
\end{aligned}
$$

であるから上記の湿分の定義式を書替えると

$$
\begin{aligned}
& M_{F}=M_{T}+M_{A} \times \frac{100-M_{T}}{100-M_{A}} \\
& M_{F^{F}}=M_{T}+M_{A} \times \frac{1-\frac{w_{1}+w_{2}}{a+w_{1}+w_{2}}}{1+\frac{w_{2}}{a+w_{2}}} \\
&=M_{F}+M_{A} \times \frac{a+w_{2}}{a+w_{1}+w_{2}} \\
&=M_{T}+M_{A} \times\left(1-\frac{w_{1}}{a+w_{1}+w_{2}}\right) \\
& \therefore M_{F}=M_{T}+M_{A}\left(1-\frac{M_{F}}{100}\right) \\
& \text { したがつて } M_{T}=M_{F}-M_{A} \times \frac{100-M_{F}}{100} \\
& \text { 全水分\% }=\text { 湿分\%-(恒湿水分\%) } \\
& \frac{100 \text { - 湿分\% }}{100}
\end{aligned}
$$

(JIS M 8802)

となる。いいか劣れば現行法は湿分を先に定義して次 に全水分を定義したので山るが，湿分の測定が正確を 期するのに困難性があるので逆汇全水分を定義して次 に湿分を定義しょうということになつたのである。何 れから定義してる一致するためには湿分測定後の石炭 と工業分析用の恒湿試料とが全く同一物であるという ことと, 湿分測定後の試料る分析用恒湿試料も107土 $2{ }^{\circ} \mathrm{C}$ で乾燥したとき重量減少\%が同一であるという前 提条件が满されていなければならない。しかし实際に はこの期待を証明することが行われていないので今後 の問題として残されることになる。現実の問題として は粒度が異れば恒湿試料の水分も異る2のので石炭の評 価の標準として分析用恒試料の発熱量が用いられる以 上恒湿試料の水分と全水分とを用いて湿分を計算する 妥当性を認めてよいであろう。もちろんこの場合には 粒度の大小関せず $107 \pm 2{ }^{\circ} \mathrm{C} て ゙$ 恒量汇達するまで乾 燥するときの重量減少\%は一定であるといら仮定がな されている。しかしこの仮定治前記全水分測定帮験の $10 \mathrm{~mm}$ と $3 \mathrm{~mm}$ の試料についての結果から類推してあ まり無理なるのとは思觉ないので妥当と考えてよいだ ろう。

\section{交献}

1) ASTM, B. S.は周知の例である。

2) Karl Drekopf and Hartwin Steiner グルック アゥフ 第 5 巻 8 号 427〜430 (1956).

後記, 本報告の講演後 ISO/TC 27 WG 20E April (1957). Proposed Draft ISO Recommendation for the Determination of the Total Moisture of Coal が大手された。その概要を参考として略記しておく。 2 段法

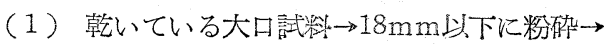


$2 \mathrm{~kg}$ 江縮分 $\rightarrow$ A水分測定 $\rightarrow 3 \mathrm{~mm}$ 以下汾砕 $\rightarrow 250 \mathrm{~g}$ 淨分 $\rightarrow \mathrm{a}$ または $\mathrm{b}$

a. $10 \mathrm{~g}$ 試料をとり $105 \sim 110^{\circ} \mathrm{C}$ の咥素 (一般の石 炭に適用）または空気（水分 $4 \%$ 以下のものに だけ適用）中でB水分測定

b. $100 \mathrm{~g}$ 試料をトルエンまたはキシレンで蒸留

(2) 濡孔ている大口試料 $\rightarrow$ A水分測定 $\rightarrow 18 \mathrm{~mm}$ 以下に粉䂶 $\rightarrow 2 \mathrm{~kg}$ に縮分 $\rightarrow 3 \mathrm{~mm}$ 以下に粉碎 $\rightarrow$ $250 \mathrm{~g}$ 縮分 $\rightarrow$ 以下 (1) と同じ。
1 段法

（1）大口試料 $\rightarrow$ 密閉粉砕機で $3 \mathrm{~mm}$ 以下に粉砕 $\rightarrow 250 \mathrm{~g}$ 江縮分 $\rightarrow$ 熱乾燥法 または 共沸蒸留法

（2）乾いた高級炭大口試料 $\rightarrow 18 \mathrm{~mm}$ 以下の粉础 $\rightarrow 2 \mathrm{~kg}$ 桜縮分 $\rightarrow 105 \sim 110^{\circ} \mathrm{C}$ の空気中で乾燥 本報告の JIS 案と異る点はA 水分測定試料の粒径が $18 \mathrm{~mm} 2 \mathrm{~kg}$ であることと， B 水分測定試料が $3 \mathrm{~mm}$ $10 \mathrm{~g}$ であることとである。

\section{恒湿水分, 気乾水分, 包蔵水分}

$\begin{array}{llll}\text { 三井鉱山株式会社 寺 } & \text { 元 } & \text { 俊 } & \text { 一 } \\ \text { 東 大 } \text { 工学 部 石 } & \text { 馨 }\end{array}$

\section{I 第 1 回協同実験}

現行 JIS 検討のため，日科技連主催のもとに全国 45 ケ所各級炭に亘り 20 孷種を兄らび，共通試料を配布 し協同実験を行つた1)。この結果を要約すれば，次の とおりである。

1.1 実験方法 現行JIS规定のと招り。

1.2 結果の検討 現行 JIS により管理された条件で 実験を行つた場合の結果を検討すれば：一

1.2.1 管理条件について

現行JISにおいて行つたが，因子にはつきのような バラッキがある。

（1）試料を恒湿にする場合の放置時間は 24〜 1,464時間に亘つている。

(2) 試料容器は, 時計血, 秤量瓶, $\mathrm{Al}$ 容器, $\mathrm{Ni}$ 剒佩等まちまちである。

（3）乾燥装置に試料を装入することによる降下 温度の回復時間は，0〜23 分に亘つている。

（4）乾燥試料の冷却時間は 30〜180 分に亘つて いる。

以上のごとく，さらに厳密に管理条件を規定する必 要のあることが認められた。

\subsection{2 許容差}

許容差をみるため, 層別して電気乾燥器を採り, こ れについて解析した結果は次のと拈りである。

第 1 表 許容差 $n=2$ (水分\%)

\begin{tabular}{|c|c|c|c|c|c|}
\hline 炭 種 & $\bar{X} \%$ & $\bar{R}$ & $D_{4} \bar{R}$ & $D_{2} \sigma \bar{x}$ & $D_{2} \sigma_{\bar{x}} / D_{4} \bar{R}$ \\
\hline 歴 青 炭 & 1.22 & 0.10 & 0.217 & 0.812 & 3.7 \\
\hline 业泟青崖 & 4.18 & 0.11 & 0.239 & 0.950 & 4.0 \\
\hline ッ崖 & 9.76 & 0.18 & 0.392 & 2.597 & 6.6 \\
\hline & 16.01 & 0.23 & 0.501 & 7.100 & 14.2 \\
\hline
\end{tabular}

以上のごとく精度比が非常に大きく, 現行 JIS の管 理条件では不十分であることを示している。

\section{II 第 2 回協同实験}

第 1 回協同実験の結果から，效界をあた少ていると 思わ礼る因子を光らんで，東京に和ける8 所で各級 炭より 5 炭種を兄らび共通試桲を配布して第 2 回の協 同実験が笑施された22。実験の方法は次の条件示す 通りである。

\section{1 とりあげた因子}

条件としては “恒湿の状態”“試料容器” “軲燥方法” “処理後の冷却”を因子として採り，各因子につき次 のごとき水集を設けた。 